\title{
COUNTERMEASURE AGAINST GROUND FLOW FOR A ROAD BRIDGE (HANSHIN EXPRESSWAY)
}

\author{
Atsushi NANJO ${ }^{1}$, Nobuhiko HAMADA ${ }^{2}$, and Manabu ITOH $^{3}$ \\ ${ }^{1}$ Member of JAEE, Manager, First Engineering Division, Engineering Department, Hanshin \\ Expressway Public Corporation, Osaka, Japan, atsushi-nanjo@hepc.go.jp \\ ${ }^{2}$ Member of JAEE, Manager, Design Division, Osaka construction Bureau, Hanshin Expressway \\ Public Corporation, Osaka, Japan, nobuhiko-hamada@hepc.go.jp \\ ${ }^{3}$ Chief Engineer, First Engineering Division, Engineering Department, Hanshin Expressway Public \\ Corporation, Osaka, Japan, manabu-ito@hepc.go.jp
}

\begin{abstract}
Hanshin Expressway Public Corporation has struggled with the restoration and retrofit program for the foundations at Bay-shore Route since the 1995 Hyogoken-Nambu Earthquake. Damage to bored piles and their remediation work are overviewed here. Particularly some of the additional pile methods were discussed as one of the countermeasures against ground flow following the liquefaction.
\end{abstract}

Key Words: Ground flow, liquefaction, bored pile, additional pile method

\section{INTRODUCTION}

The Hanshin Expressway No.5 Bay-shore Route located along the water front area of the Osaka Bay passes through several reclaimed lands and has many long span bridges crossing over waterways of $200 \mathrm{~m}$ to $900 \mathrm{~m}$ wide, as shown in Figure 1. Damages to superstructures caused by the

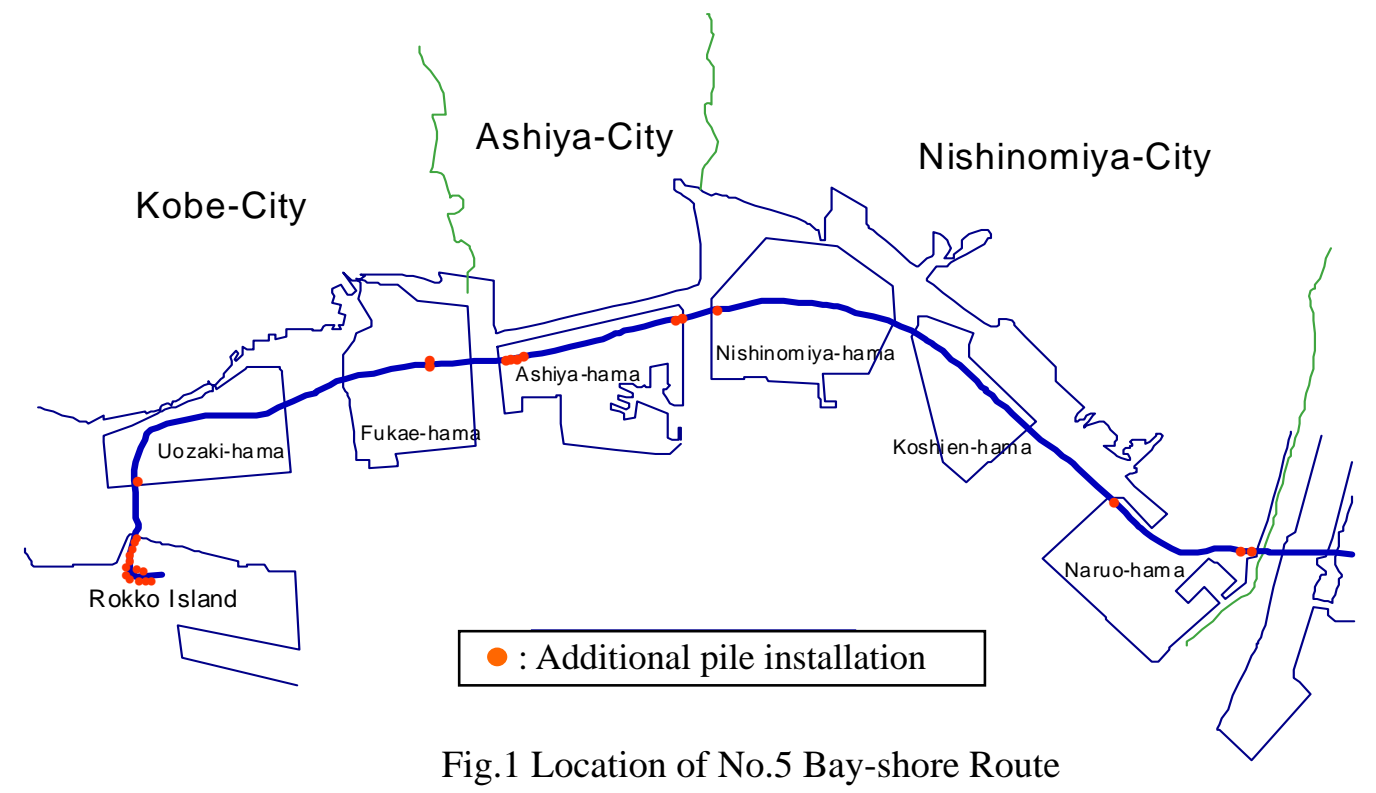


Hyogoken-Nambu Earthquake occurred markedly at the long span bridges and were mainly step gaps on the road surface or side-shifts of girders. Regarding substructures, on the other hand, damages to piers were slight even near the epicenter in Hyogo Prefecture because they were constructed according to 1980 year or later versions of Specifications for Highway Bridges. Foundations were, however, extensively damaged due to liquefaction of soil accompanied by ground flow since the No.5 Bay-shore Route was constructed at reclaimed lands with $9 \mathrm{~m}$ to $22 \mathrm{~m}$ reclamation deep.

\section{DAMAGE TO BRIDGE FOUNDATION}

Ground near waterways markedly moved towards waterways accompanying with seawalls. As residual displacements of some bridge foundations exceeded $500 \mathrm{~mm}$ due to the ground flow, external forces on piles could be lager than those expected in the design codes that were effective at the time of earthquake. Figure 2 shows a typical example of damages to seawall and neighboring bridge foundation.

Figure 3 compares the liquefaction-induced residual lateral displacements of ground and pile head respectively versus the distance from the seawall. Lateral displacements of foundation are large within a distance of $100 \mathrm{~m}$ from seawall and reach about $1.0 \mathrm{~m}$ at the maximum. They are slight at more than $100 \mathrm{~m}$ far from the seawall. Lateral displacements of ground also reach more than $2 \mathrm{~m}$ within a distance of $100 \mathrm{~m}$ and less than $0.5 \mathrm{~m}$ at more than $100 \mathrm{~m}$ from the seawall. The influential distance of ground flow is, thus, estimated within about $100 \mathrm{~m}$ from the seawall. The design method for the lateral flow of foundation near the seawall was, then, revised in the present version of Specifications for Highway Bridges.

The influence of lateral ground flow was reflected in the design of bridge foundations located near waterways around reclaimed lands in the restoration project of the No.5 Bay-shore Route. It was carried out based on the results of the investigation and the revised specifications. Degrees of damage to the foundations were judged based on the crack conditions of pile bodies observed by the bore-hole scanner as well as the residual lateral displacement.

Measures to restore a foundation are generally classified into the additional pile installation, soil improvement, chemical grouting and so on. Regarding bridge foundations located near waterways and suffered from the influence of ground flow, the stiffness of foundation was increased as a whole by additional pile installation method consisting of pile installations and the expansion of the existing footing to connect each other in order to cope with further ground flow in future.
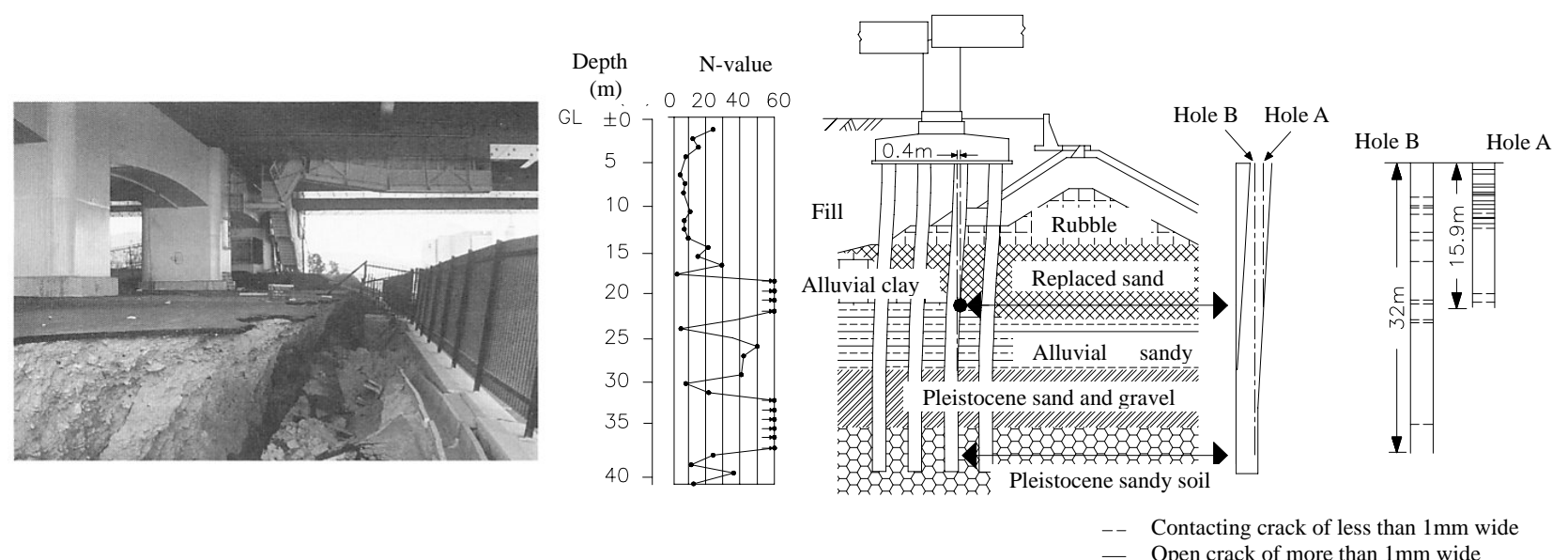

Fig.2 Example of damage to seawall and adjacent piles 


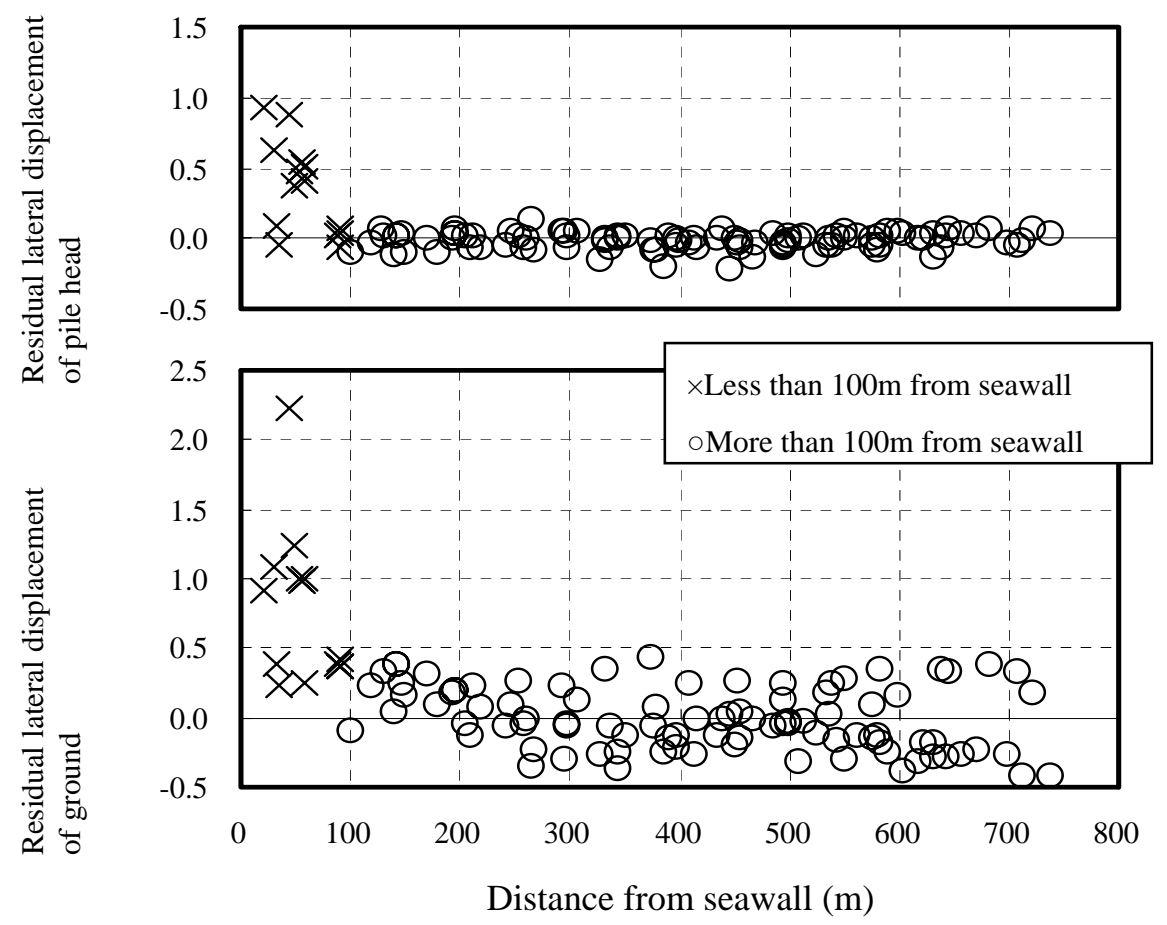

Fig.3 Lateral displacements of foundation/ground vs. distance from seawall

\section{RETROFIT DESIGN OF FOUNDATION AGAINST GROUND FLOW}

The mechanism of ground-flow-induced damage to structures was investigated prior to the design of restoration. As the result, damage mechanism consisting of the following four steps was estimated as shown in Figure 4: (I) Occurrence of earthquake and response of structures. (II) Occurrence of liquefaction, damage to shoes and hinges, damage to pile bodies following the main shock of the earthquake. (III) Occurrence of rapid ground flow propagation for back-filling, the crack between the foundation and the seawall and larger lateral pressure acting on piles following the movement of the seawall. (IV) Progress of the pile damage accompanying the ground flow. Figure 5 shows the brief design procedure of the additional pile installation method to restore the damaged foundation of bridge.

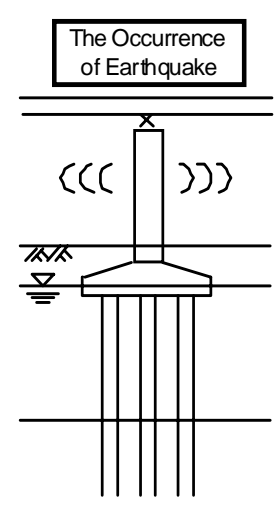

I

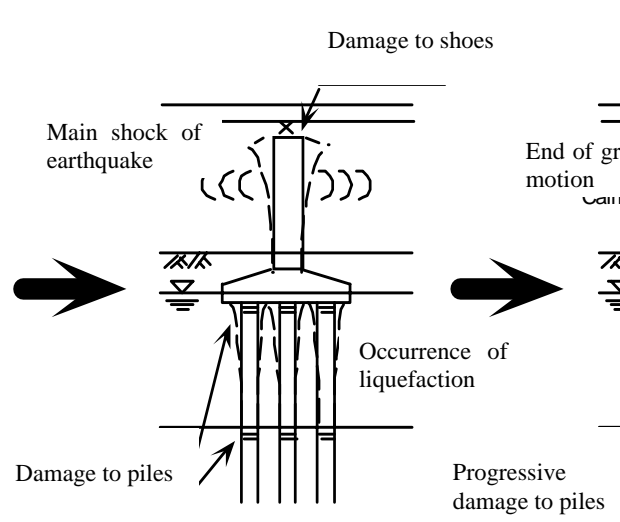

II

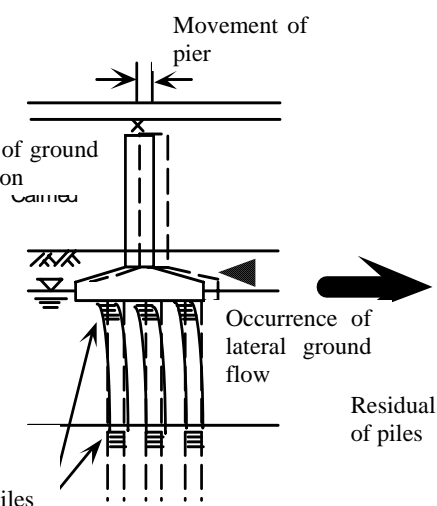

III

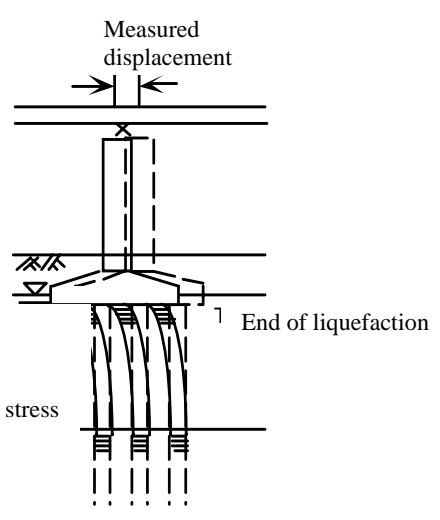

IV

Fig.4 Mechanism of ground-flow-induced damage 


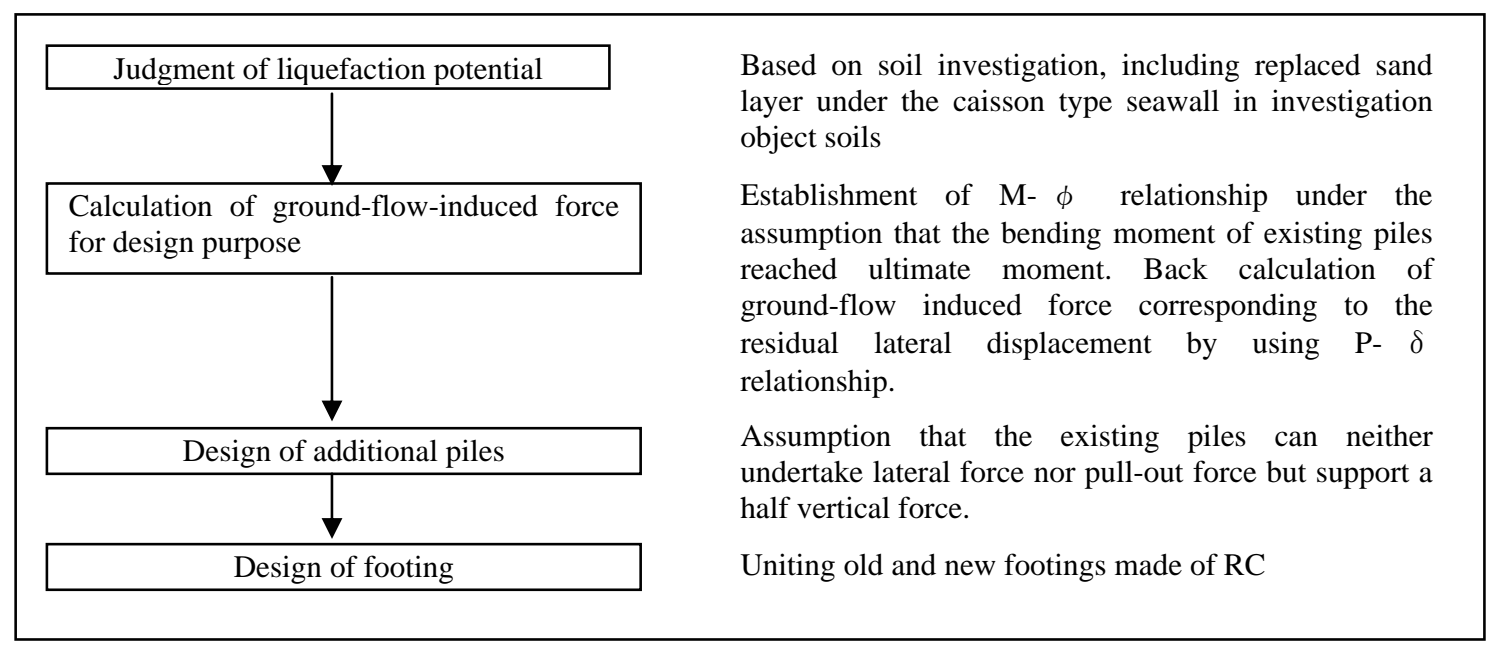

Fig.5 Brief design procedure of additional pile foundation

\section{CONSTRUCTION OF COUNTERMEASURE AGAINST GROUND FLOW}

While hybrid steel pipe piles which were installed in bore holes were used for some piers due to design and construction reasons, all the other additional piles were cast-in-place concrete piles. The diameter of additional pile was 3,000 $\mathrm{mm}$ for piers close to the waterfront as seen in Figure 6 and $2,000 \mathrm{~mm}$ for the other piers located inland of reclaimed lands. The all rotational casing excavator which was developed as a large cross sectional rock excavator was used to excavate bore holes for cast-in place piles with a diameter of 3,000 $\mathrm{mm}$. Since the force to withdraw the casing was very large, peripheral soil was improved to secure enough shear strength of soil for supporting spikes being buried as the reaction devise. The largest issue regarding execution was the capacity of withdrawing the casing. This issue was solved and the excess increase in friction was avoided by cutting friction during excavation and decreasing friction through rotating the casing at a constant time interval. The rebar cage consisted of double reinforcing steel with large diameter ranging from $38 \mathrm{~mm}$ to $41 \mathrm{~mm}$. Since the cage had many joints and was heavy, the installation required 2 days each.

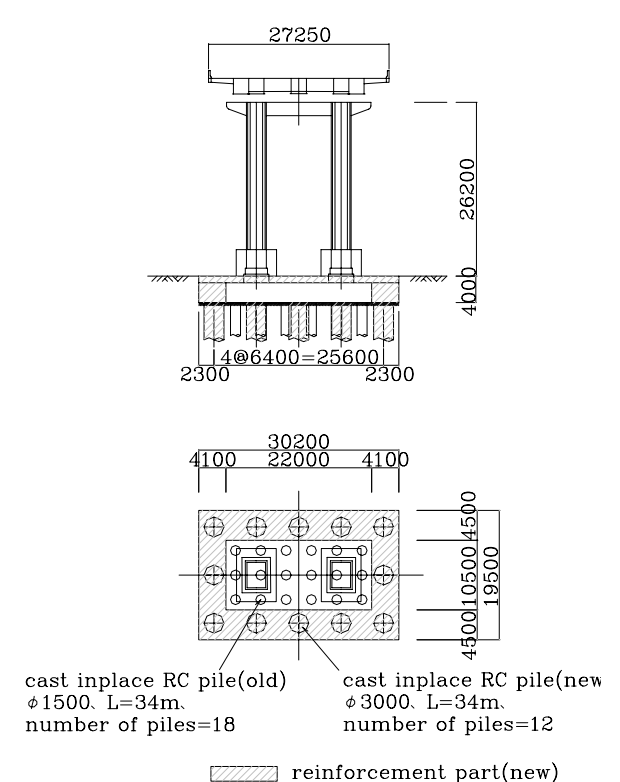

Fig.6 Standard reinforcement by additional piles

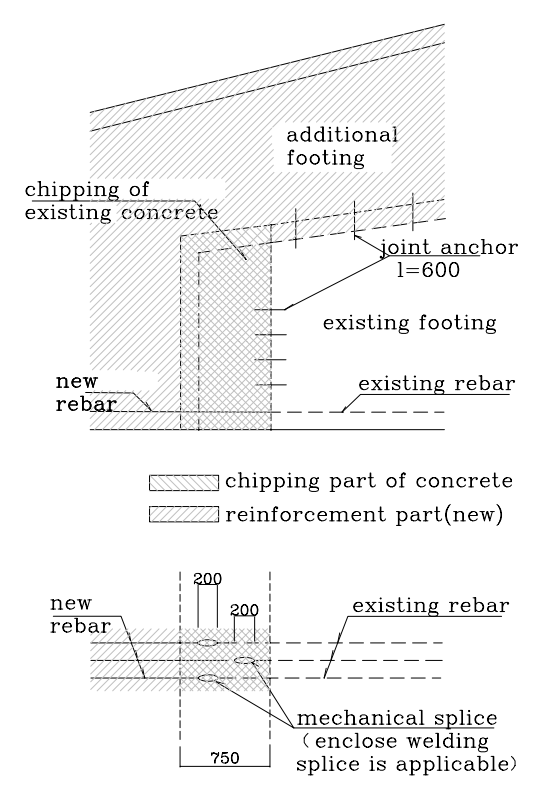

Fig.7 Connection of old and new footings 
The new main reinforcements were connected to existing main reinforcements with the mechanical splices and the joint anchors to connect both footings, as seen in Figure 7. The enclosed welding splice was approved to use because of its easy handling and enough quality, as seen in Figure 8.

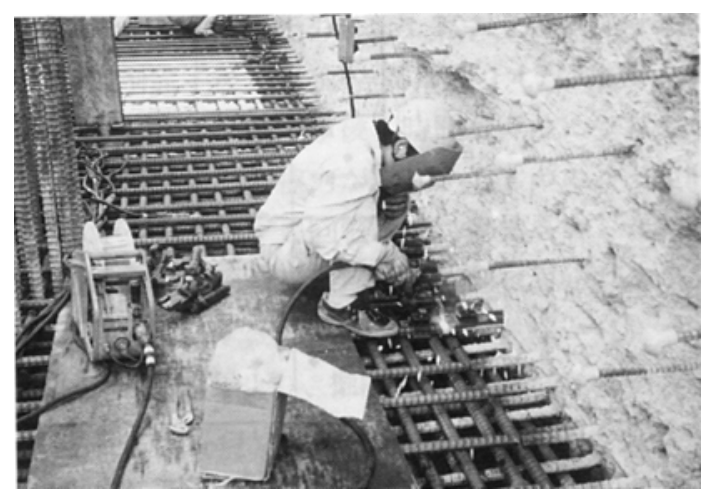

Fig.8 View of enclosed welding

The piers located at Ashiya-hama supported the wide superstructure portion for the concentrated toll gates on the main lanes and the operation height was as low as $7 \mathrm{~m}$ under the girder. Since the length of a rebar cage piece had to be only about $3 \mathrm{~m}$ and it was considered to be inefficient to adopt cast-in-place piles, the hybrid steel pipe piles having a diameter of 2,500 mm shown in Figure 9 were adopted. After excavation by the all rotational casing excavator with a diameter of 3,000 mm, pieces of steel pipe were installed by welding one by one. The top of the pile was connected to the footing according to Connecting Method B specified in Specifications for Highway Bridges. Since this pier was adjacent to the seawall, the least amount of chemical grouting and the deep well method were applied to cut water off and drain water, respectively.

The foundation retrofit at east end of Naruo-hama reclaimed land on the right shore of the Muko river is shown in Figure 10. The hybrid steel pipe piles having a diameter of 2,000 mm were used at the upper portion where the predicted cross sectional forces was large, and the cast-in-place reinforced concrete pile was used for lower portion at this site. The execution procedures were as follows: (I) Excavation to the pre-determined depth with the steel pipe having a diameter of 2,000 mm. This pipe with ribs was used also as a casing. (II) Insertion of the casing having a diameter of 1,800 $\mathrm{mm}$ to the bottom of the above-mentioned hole and further excavation with the casing to the other pre-determined depth. (III) Insertion of rebar cages to the bottom of the bore hole. (IV) Withdrawing the casing during concrete casting.

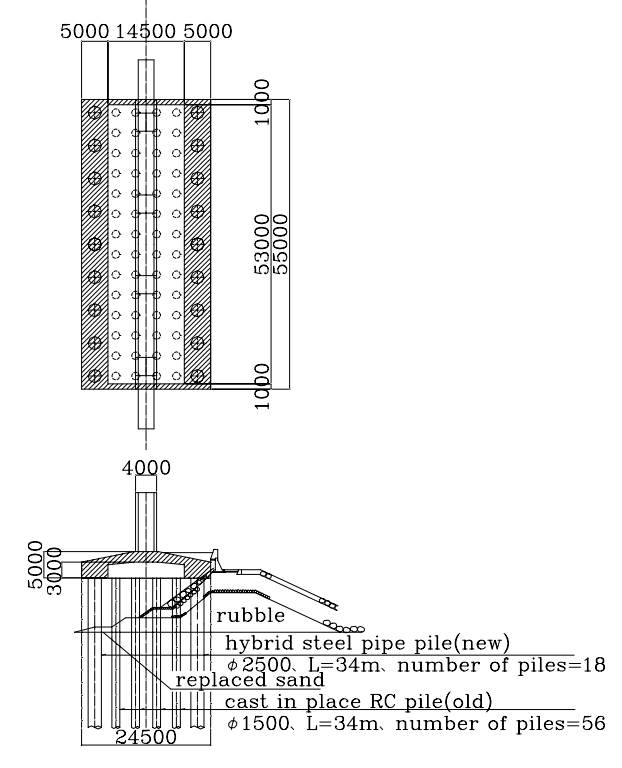

Fig.9 Reinforcement by hybrid steel pipe pile

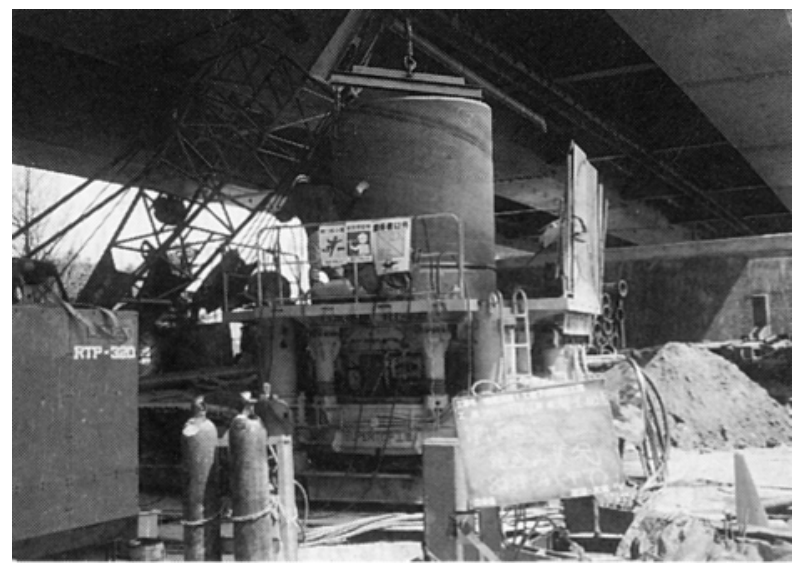

Fig.10 Connecting process of steel pipes with ribs 
Furthermore, ground around piers located between Amagasaki-City and Kobe-City along the No.5 Bay-shore Route was improved by the Column Jet Grout (CJG) method which was one of the High-Pressure Jet Mixing Method to enhance the seismic performance against liquefaction and to suppress relative displacement of piles by confining vicinity soil during liquefaction.

\section{CONCLUSIONS}

The restoration and retrofit program for the foundations was introduced here after the 1995 Hyogoken-Nambu Earthquake. Damage to bored piles and their remediation work were overviewed. Some kinds of the additional pile methods were applied to the damaged foundation sites as one of the countermeasures against liquefaction-induced ground flow in order to improve the seismic performance of Hanshin Expressway bridge foundations.

\section{REFERENCES}

Committee on Highway Bridge Damage Caused by the Hyogo-ken Nanbu Earthquake, December 1995 (1995). "Report on Highway Bridge Damage Caused by the Hyogo-ken Nanbu Earthquake of 1995.”

Hanshin Expressway Public Corporation (1997). "Overcoming Large Earthquake-Restoration Record of Earthquake Disaster.” (in Japanese)

Ishizaki H. and Hamada N. (2000). "Restoration and Seismic Retrofit of Highway Substructure." International Association for Bridge and Structural Engineering 2000 Lucerne

Ishizaki H., Hamada N. and Egawa N. (1996). "Restoration of Foundation Structures in Hanshin Expressway Bayshore Wangan Route”, Forum for Geotechnical Engineering in Recovery from Urban Earthquake Disaster, Kansai Branch of Japanese Geotechnical Society, 275-284

Japan Road Association (1994). "Specifications/Commentaries for Highway Bridges Part IV, Substructures.” (in Japanese)

Japan Road Association (1996). "Specifications/Commentaries for Highway Bridges Part V, Seismic Design.” (in Japanese)

Kagayama T. and Egawa N. (1997). "Restoration of foundation structures along Hanshin Expressway No.5 Bay-shore Route.” Hanshin Expressway Public Corporation Technical Report No.15, (in Japanese)

Watanabe H., Ishizaki H. and Kitagawa T. (1997). "Restoration construction of bridge foundations along Hanshin Expressway No.5 Bay-shore Route.” Symposium on Seismic Resistible Reinforcement/Repair and Seismic Resistibility Diagnosis Technologies, Japan Society of Civil Engineering (in Japanese)

(Submitted: March 31, 2004)

(Accepted: June25, 2004)

Copyright JAEE 